\title{
Socio-demographic correlates of availability of adequate iodine in household salt: a community-based cross-sectional study
}

\author{
Dessalegn Ajema ${ }^{1 *}$, Muluken Bekele ${ }^{1}$, Manaye Yihune ${ }^{1}$, Hiwot Tadesse², Gebrekiros Gebremichael ${ }^{1}$ \\ and Melkamu Merid Mengesha ${ }^{3}$
}

\begin{abstract}
Objective: This study aimed to assess the availability of adequately iodized salt at a household level and associated factors in Arba Minch town, South Ethiopia using the gold standard technique, the iodometric titration.

Results: $41.8 \%$ (95\% Cl (confidence interval) 38.6 to 45.1 ) of households had inadequately iodized salt, and 9.3\% ( $95 \% \mathrm{Cl} 7.5$ to 11.4 ) had an iodine content below $10 \mathrm{ppm}$ (parts per million). Compared to households with a monthly income of greater than 2000 ETB (Ethiopian Birr), households with a monthly income between 1000 ETB to 2000 ETB (adjusted odds ratio $(A O R)=0.52,95 \% \mathrm{Cl} 0.390 .36$ to 00.77 ) and main food handlers aged 30 years or above compared to those aged less than 20 years of age $(a \mathrm{OR}=0.55,95 \% \mathrm{Cl} 0.34$ to 0.91$)$ had higher odds of having adequately iodized salt. Food handler's knowledge and practice were not found to be correlated with the availability of adequately iodized salt in household salt.
\end{abstract}

Keywords: Iodine availability, Household salt, Prevalence, Associated factors, South Ethiopia

\section{Introduction}

Iodine deficiency, one of the most prevalent micronutrient deficiencies globally with two billion individuals estimated to have an insufficient iodine intake $[1,2]$, is the main cause of potentially preventable cognitive disability in childhood [3]. When iodine requirements go unmet, synthesis of thyroid hormones is impaired, resulting in a spectrum of growth, developmental and functional abnormalities referred to as iodine deficiency disorders (IDD) [4]. Iodine deficiency most affected people in subSaharan Africa and Southeast Asia [2].

Globally, there have been major achievements to prevent iodine deficiency between 2003 and 2011, the number of countries with adequate iodine intake increased

\footnotetext{
*Correspondence: dessu.aj@gmail.com

${ }^{1}$ Department of Public Health, College of Medicine and Health Sciences,

Arba Minch University, Arba Minch, Ethiopia

Full list of author information is available at the end of the article
}

from 67 to 105 [5]. Despite these gains, sharp regional differences persist [5].

In Ethiopia, for the past six decades, IDDs has been recognized as a serious public health problem. An estimated 66 million people had an insufficient iodine intake and remain unprotected from iodine deficiency in 2011, with only $15 \%$ of households had access to adequately iodized salt [6]. Despite the government of Ethiopia planned to achieve $90 \%$ of households use adequately iodized salt by the year 2015 , only $25.8 \%$ of households succeeded, and hence iodine deficiency has continued to be a critical public health problem in Ethiopia [7].

Only $12.2 \%$ of the households were using iodized salt in the Southern nation, nationalities, and peoples region (SNNPR), which is quite below the national level [8]. Evidence on the availability of adequately iodized salt at the household level, in areas located over $1000 \mathrm{~km}$ from the production site, is not well studied in a large sample using the gold standard iodometric titration [9]. 


\section{Main text \\ Methods}

\section{Study design and population}

A community-based cross-sectional study was conducted in Arba Minch town in June 2017. Study participants were primary food handlers, a household member who is mostly involved in food preparation and aged 18 years old or more. Primary food handlers who were sick or unable to respond were excluded from the study.

\section{Sample size determination and sampling procedures}

The sample size was calculated using Epi Info version 7 considering different parameters: 95\% level of confidence, magnitude of adequately iodized salt $=33 \%$ [10], $4 \%$ margin of error, 1.5 design effect, and $10 \%$ nonresponse rate. Accordingly, the minimum calculated sample size was 875 .

A multistage sampling technique was used to select households included in the study setting. At the first stage, we randomly selected four of the 11 kebeles (the lowest administrative unit) in the town, and households within each of the selected kebeles, in turn, are selected using a systematic random sampling technique.

\section{Data collection and quality management}

A structured questionnaire adapted from the iodized salt program assessment tool was used to conduct a face-to-face interview [11]. Using a plastic bag, 20-g sample (2-3 teaspoons) of salt was collected from each household and the iodine level was determined using iodometric titration in Arba Minch University biochemistry laboratory under quality control measures.

\section{Procedure to test the iodine content of salt}

A $10 \mathrm{~g}$ iodized salt is dissolved in $50 \mathrm{ml}$ distilled water after ensuring the sample salt was thoroughly mixed in zip-lock bags. Once the salt is dissolved in the measured amount of water, $2 \mathrm{ml}$ sulfuric acid and $5 \mathrm{ml}$ potassium iodide are added to the salt solution, which in the presence of iodine, will turn yellow. The reaction mixture was then kept in a dark place (with no exposure to light) for $10 \mathrm{~min}$ to reach the optimal reaction time before titrated with sodium thiosulfate using starch $(2 \mathrm{ml})$ as the indirect indicator [8]. Adequately iodized salt at household level was defined when a salt sample has $\geq 15$ parts per million (PPM) of iodine [12].

\section{Knowledge about iodized salt}

Five questions assessed knowledge, and participants who scored above the median in the overall knowledge score were considered as having good knowledge and poor otherwise.

\section{The practice of household salt handling}

There were eight practice questions and participants who scored above the median for the practice questions on household salt handling were considered as having good practice and poor otherwise.

\section{Data management and analysis procedures}

Data were entered into Epi info version 7, and then exported to STATA version 14.2 for cleaning and data analysis. Results were presented using descriptive summary statistics for continuous variables and percentages for categorical variables and also presented in a diagram and in tables. Pearson's Chi square test and a one-way Analysis Of Variance (ANOVA) were used to see if there was an association between two categorical variables and variation in mean iodine level by level of a factor variable, respectively. The binary logistic regression model was used to identify factors associated with the level of iodine in household salt. Finally, variables with $\mathrm{P}<0.05$ in the multivariable analysis were considered as significant.

\section{Results}

Socio-demographic characteristics

A total of 875 subjects, representing a $100 \%$ response rate, participated in this study, of whom, males constituted only $6.3 \%$. The mean age was 31.1 years (Table 1 ).

\section{Level of adequately iodized salt in household salt}

The proportion of households with adequate iodine content in household salt was $58.2 \%$ (95\% CI 54.5 to 61.4 ). Of the households with inadequately iodized salt, $41.8 \%$ (95\% CI 38.6 to 45.1 ), 9.2\% (95\% CI 7.5 to 11.4 ) had an iodine content below $10 \mathrm{ppm}$. The overall mean level of iodine content in a household sample of salt was 16.4 $\mathrm{ppm}( \pm 5.4)$.

There was a comparable level of knowledge about iodized salt among participants in households with inadequate versus adequate iodine content in salt, $68.3 \%$ versus $71.5 \%$. There was no significant difference in the level of household iodine content by participant's knowledge (Fig. 1).

\section{Knowledge about iodized salt}

Seventy percent of the participants reported that they had heard about iodized salt before this survey, and $26.2 \%$ did not know the negative effects associated with iodine deficiency. The commonly mentioned effect of iodine deficiency was goiter, among $60 \%$ of respondents. 
Table 1 Socio-demographic characteristics of respondents in Arba Minch town, Gamo Zone, South Ethiopia, 2017

\begin{tabular}{|c|c|c|}
\hline Variables & Frequency & Percent (\%) \\
\hline \multicolumn{3}{|l|}{ Sex } \\
\hline Female & 820 & 93.7 \\
\hline Male & 55 & 6.3 \\
\hline \multicolumn{3}{|l|}{ Age category } \\
\hline$<19$ & 106 & 12.1 \\
\hline $20-29$ & 351 & 40.1 \\
\hline $30-29$ & 218 & 24.9 \\
\hline $40-49$ & 121 & 13.8 \\
\hline $50+$ & 79 & 9.0 \\
\hline Age, mean $(95 \% \mathrm{Cl})$ & $31.1(30.4,31.8)$ & \\
\hline \multicolumn{3}{|l|}{ Religion } \\
\hline Protestant & 415 & 47.4 \\
\hline Orthodox & 360 & 41.1 \\
\hline Muslim & 100 & 11.4 \\
\hline \multicolumn{3}{|l|}{ Educational status } \\
\hline Diploma or higher & 335 & 38.3 \\
\hline Do not read and write & 235 & 26.9 \\
\hline Grade 9-12 & 159 & 18.2 \\
\hline Grade 1-8 & 146 & 16.7 \\
\hline \multicolumn{3}{|l|}{ Occupation } \\
\hline Private business & 300 & 34.3 \\
\hline Student & 183 & 20.9 \\
\hline Government employee & 165 & 18.9 \\
\hline Merchant & 129 & 14.7 \\
\hline Farmer/or housewife & 98 & 11.2 \\
\hline \multicolumn{3}{|l|}{ Marital status } \\
\hline Married & 561 & 64.1 \\
\hline Single & 261 & 29.9 \\
\hline Widowed & 27 & 3.1 \\
\hline Divorced & 26 & 3.0 \\
\hline \multicolumn{3}{|l|}{ Household monthly income } \\
\hline$<1000$ ETB & 384 & 43.9 \\
\hline $1000-2000$ ETB & 198 & 22.6 \\
\hline$>2000$ ETB & 293 & 33.5 \\
\hline \multicolumn{3}{|l|}{ Household family size } \\
\hline$<5$ & 658 & 75.2 \\
\hline$\geq 5$ & 217 & 24.8 \\
\hline
\end{tabular}

Regarding the benefits of iodized salt, 5.2\% said it is used just for a flavor, and $33.6 \%$ reported they do not know its benefit. Similarly, $49.7 \%$ said unfavorable transport or storage of iodized salt reduces its content.

\section{The practice of iodized salt utilization}

The majority of respondents practiced appropriate handling of iodized salt concerning avoiding exposure to sunlight (84\%), placing it in a dry area (94.2\%), and storing it in a covered container (72.7\%). However, $55.0 \%$ buy unpacked salt, $27.3 \%$ buy from an open market, $35.5 \%$ store for 2 or 3 months, and $55.1 \%$ add salt early or in the middle of cooking time which altogether contribute to the consumption of reduced level of iodine.

The mean level of iodine in household salt which was obtained from an open market versus a retailer's shop or a supermarket was $15.3 \mathrm{ppm}$ and $16.8 \mathrm{ppm}$ which had a significant difference $(F \quad(1873)=13.11$, P-value $<0.001)$, respectively. Similarly, the mean level of iodine significantly varied in household salt which was packed (17.2 ppm) versus unpacked (15.8 ppm), (F $(1873)=16.34$, P-value $<0.001)$.

\section{Factors associated with adequate iodine level in household salt}

There were increased odds that adequately iodized salt would be available in households where the main food handler was Orthodox compared to a Protestant by religion $(\mathrm{aOR}$ (adjusted odds ratio) $=1.50,95 \% \mathrm{CI} 1.10$ to 2.03). However, there were reduced odds that adequately iodized salt would be available in households where the main food handler was older than 30 years $(\mathrm{aOR}=0.50$, 95\% CI 0.30 to 0.85 ) compared to those under 20 years of age and in households where monthly income was between 1000 ETB to 2000 ETB compared those earning greater than $2000 \mathrm{ETB}(\mathrm{aOR}=0.58,95 \% \mathrm{CI} 0.39$ to 0.86 ) (Table 2).

\section{Discussion}

The proportion of households with adequately iodized salt at the national level in Ethiopia was only 25.8\%, with a great sub-national variation [7]. We found that only $58.2 \%$ of households had adequately iodized salt.

The estimated proportion of households with an adequate level of iodine in Arba Minch town, 52.8\%, was higher compared to the sub-national estimate for SNNPR, 13.7\% [7], and also compared to a study in Wolaita zone, $37.7 \%$ [9]. Our sample, however, was restricted to households located in an urban area, and different studies reported a higher level of iodine content in urban than rural areas [9, 13-15]. Consistent with our finding, a study in southwest Ethiopia, Dera district, reported that $57.4 \%$ of households had an adequately iodized salt ( $\geq 15 \mathrm{ppm}$ ) [16]. Compared to our finding, Mekonnen et al. reported a lower proportion of households with adequately iodized salt in Kombolcha town, 35\%, and a higher level in Dessie, 78\% [15].

The proportion of households consuming adequately iodized salt in the study setting, $58.2 \%$, was very low compared to the WHO recommendation of $>90 \%$ 


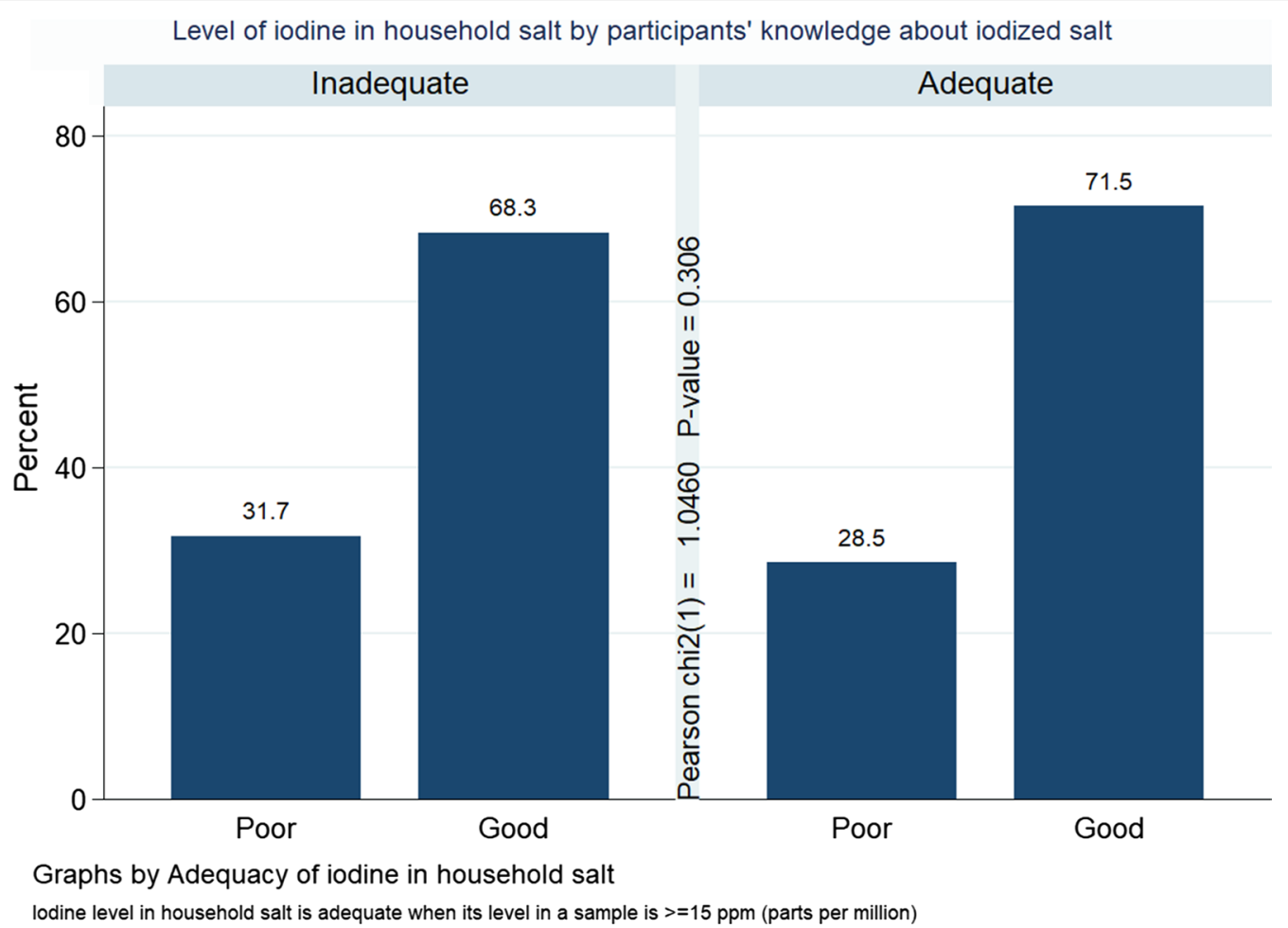

Fig. 1 Household salt lodine level by participants' knowledge in Arba Minch town, Gamo Zone, South Ethiopia, 2017

[17]. Though iodine can be obtained from several food sources, iodine-rich foods are not available everywhere [2], and hence consumption of iodized salt is the mainstay of preventing IDDs [2]. Research evidence indicated that IDD can be manifested across the life span [17] which in turn signifies the importance of reducing iodine deficiency.

We found that household monthly income and age and religion of primary food handler had a significant association with the level of iodine in household salt. Similar findings were reported in previous studies [14-16, 18, 19]. Inadequate iodine content was more likely in households where a primary food handler was of age 30 years or more as reported in previous studies [16, 19]. As we found that there was variation in iodine content by religion, a similar finding was reported by Sen et al. where consumption of adequately iodized salt was lower among Muslims [18].

Against our expectation, the respondent's knowledge of iodized salt and handling practices had no statistically significant association with the availability of adequate iodine in household salt. A previous similar study in Addis Ababa, however, reported that level of the knowledge does not affect the availability of adequately iodized salt in household salt [20]. We justify our finding by fact that, in the year when this study was conducted, several firms were producing and distributing salt to consumers with unregulated quality [21], and hence access to mixed quality of iodized salt may underestimate the effect of consumer's knowledge about iodized salt and handling practice in maintaining iodine in household salt. A study by Mekonnen et al. in South Wollo, Ethiopia, identified firms that distribute table salt with no iodine or inadequate iodine [15]. Similarly, substantial loss of iodine content of salt in the supply chain as high as $57 \%$ from production was also reported [22].

\section{Limitation of the study}

The limitations of our study could be that we did not address the level of iodine in salt at the production site or in a retailer's shop where households purchase. Furthermore, as our study was limited only to the urban areas, our results were not generalizable to households in rural areas. Furthermore, social desirability bias could be another limitation of this study. 
Table 2 Analysis of factors associated with availability of adequately iodized salt in Arba Minch town, Gamo Zone, South Ethiopia, 2017

\begin{tabular}{|c|c|c|c|c|}
\hline \multirow[t]{2}{*}{ Variables } & \multicolumn{2}{|c|}{ Level of iodine in a sample of household salt } & \multirow[t]{2}{*}{ COR, $95 \% \mathrm{Cl}$} & \multirow[t]{2}{*}{ AOR, $95 \% \mathrm{Cl}$} \\
\hline & $\geq 15 \mathrm{ppm}$ & $<15$ ppm & & \\
\hline \multicolumn{5}{|l|}{ Sex } \\
\hline Female & 475 & 345 & $0.85(0.49,1.49)$ & \\
\hline Male & 34 & 21 & Ref. & \\
\hline \multicolumn{5}{|l|}{ Age category } \\
\hline$<19$ & 70 & 36 & Ref. & Ref. \\
\hline $20-29$ & 209 & 142 & $0.71(0.45,1.14)$ & $0.74(0.46,1.20)$ \\
\hline $30+$ & 230 & 188 & $0.62(0.39,0.98)^{*}$ & $0.55(0.34,0.91)^{*}$ \\
\hline \multicolumn{5}{|l|}{ Educational status } \\
\hline Do not read and write & 126 & 109 & $0.83(0.59,1.16)$ & 1. $11(0.74,1.67)$ \\
\hline Grade 1-8 & 89 & 57 & $1.12(0.75,1.67)$ & $1.34(0.88,2.07)$ \\
\hline Grade 9-12 & 99 & 60 & $1.18(0.80,1.74)$ & $1.24(0.83,1.86)$ \\
\hline Diploma or higher & 195 & 140 & Ref. & Ref. \\
\hline \multicolumn{5}{|l|}{ Occupation } \\
\hline Farmer/or housewife & 47 & 51 & $0.61(0.37,1.00)$ & \\
\hline Merchant & 80 & 49 & $1.08(0.68,1.72)$ & \\
\hline Government employee & 96 & 69 & $0.92(0.60,1.42)$ & \\
\hline Private business & 176 & 124 & $0.94(0.65,1.37)$ & \\
\hline Student & 110 & 73 & Ref. & \\
\hline \multicolumn{5}{|l|}{ Marital status } \\
\hline Married & 326 & 235 & $0.91(0.51,1.62)$ & \\
\hline Single & 151 & 110 & $0.90(0.49,1.65)$ & \\
\hline Widowed/divorced & 32 & 21 & Ref. & \\
\hline \multicolumn{5}{|l|}{ Religion } \\
\hline Ethiopian orthodox & 232 & 128 & $1.61(1.20,2.15)^{* *}$ & $1.68(1.25,2.27)^{* *}$ \\
\hline Muslim & 57 & 43 & $1.17(0.76,1.82)$ & 1. $16(0.73,1.84)$ \\
\hline Protestant & 220 & 195 & Ref. & Ref. \\
\hline \multicolumn{5}{|l|}{ Household monthly income } \\
\hline$<1000$ ETB & 228 & 156 & $0.85(0.62,1.17)$ & $0.78(0.55,1.10)$ \\
\hline 1000-2000 ETB & 96 & 102 & $0.55(0.38,0.79)^{* *}$ & $0.52(0.36,0.77)^{* *}$ \\
\hline$>2000$ ETB & 185 & 108 & Ref. & Ref. \\
\hline \multicolumn{5}{|l|}{ Household family size } \\
\hline$<5$ & 389 & 269 & $1.17(0.86,1.59)$ & \\
\hline$\geq 5$ & 120 & 97 & Ref. & \\
\hline \multicolumn{5}{|l|}{ Respondent's knowledge } \\
\hline Poor & 145 & 116 & Ref. & Ref. \\
\hline Good & 364 & 250 & $0.86(0.64,1.15)$ & $1.14(0.78,1.66)$ \\
\hline \multicolumn{5}{|l|}{ Respondent's practice } \\
\hline Poor & 205 & 145 & Ref. & Ref. \\
\hline Good & 304 & 221 & $1.03(0.78,1.35)$ & $0.93(0.67,1.29)$ \\
\hline
\end{tabular}

*P-value $<0.05 *$ * P-value $<0.01$

\section{Abbreviations}

ANOVA: Analysis of variance; EDHS: Ethiopian demographic and health survey; ICCIDD: International Council for the Control of lodine Deficiency Disorders: IDD: lodine deficiency disorders; IGN: lodine global network; IQ: Intelligence quotient; PPM: Parts per million; SNNPR: Southern nation, nationalities, and peoples region; UNICEF: United Nations Children's Fund; USI: Universal salt iodization; WHO: World Health Organization.

\section{Acknowledgements}

Our sincere acknowledgement extends to the study participants and Arba Minch Health office for the base line information. We thank data collectors, laboratory technicians and supervisors for their contribution in the success of the study. 


\section{Authors' contributions}

DA conceptualized the study; DA and MM drafted the manuscript; MM and DA analyzed and interpreted the data; DA, MM, MB, MY, HT and GG have critically reviewed the draft for the intellect. All authors read and approved the final manuscript.

\section{Funding}

College of Medicine and Health Sciences, Arba Minch University.

\section{Availability of data and supporting materials}

The datasets used and analyzed during the current study will be available from the corresponding author on a reasonable request.

\section{Ethics approval and consent to participate}

Ethical clearance was obtained from the institutional review board of the department of public health, Arba Minch University, with IRB ref no. $\mathrm{CMHS} / 307 / 07$. A letter of permission was written to Arba Minch health office. Informed written consent was obtained from the respondents, after the necessary explanation about the purpose, benefits, and risks of the study and also their right on the decision of participating in the study. The assurance of confidentiality was performed by omitting the names of the study participants from the questionnaire.

\section{Consent for publication}

Not applicable.

\section{Competing interests}

The authors declare no competing interests.

\section{Author details}

1 Department of Public Health, College of Medicine and Health Sciences, Arba Minch University, Arba Minch, Ethiopia. ${ }^{2}$ Department of Nursing, College of Medicine and Health Sciences, Arba Minch University, Arba Minch, Ethiopia. ${ }^{3}$ School of Public Health, College of Health and Medical Sciences, Haramaya University, Harar, Ethiopia.

Received: 14 October 2019 Accepted: 26 February 2020

Published online: 04 March 2020

\section{References}

1. WHO. Global health risks: mortality and burden of disease attributable to selected major risks. Geneva: World Health Organization; 2009.

2. Zimmermann MB, Jooste PL, Pandav CS. lodine-deficiency disorders. Lancet. 2008;372(9645):1251-62.

3. WHO/UNICEF/ICCIDD. Indicators for assessment of iodine deficiency disorders and the control programme: report of a joint WHO/UNICEF/ ICCIDD consultation. Geneva: WHO/UNICEF/ICCIDD; 1992.

4. Delange F. The disorders induced by iodine deficiency. Thyroid. 1994:4(1):107-28

5. Andersson M, Karumbunathan V, Zimmermann MB. Global iodine status in 2011 and trends over the past decade. J Nutr. 2012;142(4):744-50.

6. Adish A, Chuko T, Abay A, Assey V, Desta T. Ethiopia breaking through with a new iodized salt law. Ethiopia: MI/UNICEF-Ethiopia/GAIN/ICCIDD lodine Network; Federal Ministry of Health; 2013.

7. EPHI. Ethiopian National Micronutrient Survey Report. Addis Ababa: Ethiopian Public Health Institute; 2016.
8. Central Statistical Agency [Ethiopia] and ICF International. Health Survey. Central Statistical Agency Addis Ababa. Maryland: Ethiopia ICF International Calverton; 2011. p. 2012.

9. Kumma WP, Haji Y, Abdurahmen J, Mehretie Adinew Y. Factors affecting the presence of adequately iodized salt at home in Wolaita, Southern Ethiopia: community based study. Int J Food Sci. 2018;2018:10.

10. Gidey B, Alemu K, Atnafu A, Kifle M, Tefera Y, Sharma H. Availability of adequate iodized salt at household level and associated factors in rural communities in Laelay Maychew District, Northern Ethiopia: a cross sectional study. J Nutr Health Sci. 2015;2(1):1.

11. Houston R, Lotfi M, Nathan R, Pandav C. Assessing country progress in universal salt iodization programs. lodized salt Program Assessment Tool (ISPAT). 1999.

12. WHO/UNICEF/ICCIDD. Assessment of iodine deficiency disorders and monitoring their elimination: a guide for programme managers 2008 [updated 1st September 2008. Third edition. http://www.who.int/nutri tion/publications/micronutrients/iodine_deficiency/9789241595827/en/.

13. Kitwa KE, Habimana L, Lumbu SJB, Donnen P, Twite KE, Mpoyo KE. Evaluation of iodine content in table salt consumed in Democratic Republic of Congo. Food Nutr Bull. 2012;33:3.

14. Knowles JM, Garrett GS, Gorstein J, Kupka R, Situma R, Yadav K. Household coverage with adequately iodized salt varies greatly between countries and by residence type and socioeconomic status within countries: results from 10 national coverage surveys. J Nutr. 2017;147:11.

15. Mekonnen TC, Eshete S, Wasihun Y, Arefaynie M, Cherie N. Availability of adequately iodized salt at household level in Dessie and Combolcha Towns, South Wollo, Ethiopia. BMC Public Health. 2018;18:9.

16. Anteneh ZA, Engidayehu M, Abeje G. lodine content of dietary salt at household level and associated factors using lodometric titration methods in Dera District, Northwest Ethiopia. BMC Nutr. 2017;3:7.

17. WHO. lodine status worldwide: WHO global database on iodine deficiency. Geneva: World Health Organization; 2004.

18. Sen TK, Das DK, Biswas AB, Chakrabarty I, Mukhopadhyay S, Roy R. Limited access to iodized salt among the poor and disadvantaged in North 24 Parganas district of West Bengal, India. J Health Popul Nutr. 2010;28(4):369-74.

19. Haji Y, Abdurahmen J, Paulos W. Knowledge and perception of consumption of iodized salt among food handlers in Southern Ethiopia. Food Nutr Bull. 2016;38(1):92-102.

20. Bazezew MM, Yallew WW, Belew AK. Knowledge and practice of iodized salt utilization among reproductive women in Addis Ababa City. BMC Res Notes. 2018;11(1):734.

21. Berhane S. Ministry Urges Afar salt to improve production. Addis Ababa: Addis Fortune; 2017.

22. Shawel D, Hagos S, Lachat CK, Kimanya ME, Kolsteren P. Post-production losses in iodine concentration of salt hamper the control of iodine deficiency disorders: a case study in Northern Ethiopia. J Health Popul Nutr. 2010;28(3):7.

\section{Publisher's Note}

Springer Nature remains neutral with regard to jurisdictional claims in published maps and institutional affiliations.

Ready to submit your research? Choose BMC and benefit from

- fast, convenient online submission

- thorough peer review by experienced researchers in your field

- rapid publication on acceptance

- support for research data, including large and complex data types

- gold Open Access which fosters wider collaboration and increased citations

- maximum visibility for your research: over 100M website views per year

At $\mathrm{BMC}$, research is always in progress.

Learn more biomedcentral.com/submissions 